\title{
Assessment of precipitation deficit using cropwat
}

\section{M.S. SUPE, S.M. TALEY AND M.U. KALE}

Received : 02.05.2015; Revised : 09.03.2015; Accepted : 20.03.2015

See end of the Paper for authors' affiliation

Correspondence to :

\section{M.S. SUPE}

Department of Soil and Water Conservation Engineering, Dr. Panjabrao Deshmukh Krishi Vidyapeeth, AKOLA (M.S.) INDIA

Email : supemital@gmail.com
- ABSTRACT : Precipitation deficit of wan river basin was assessed using CROPWAT. It also cleared that more or less the effective rainfall was constant around $600 \mathrm{~mm}$ over entire basin. Soil moisture deficit decreased from Wari Bhairavgarh to Khatkali i.e. from low to high altitude. There was no precipitation deficit in case of soybean crop whereas it was observed maximum for pigeon pea followed by cotton. Daily soil moisture deficit analysis confirmed that readily soil moisture is available though less than field capacity, to satisfy ETc need of plants up to last decade of September. Thus, two protective irrigations should required during the month of October-November for maintaining optimal growing conditions in the basin.

- KEY WORDS : Cropwat, Precipitation deficit, Pigeaonpea, Cotton, Wan river basin

- HOW TO CITE THIS PAPER : Supe, M.S., Taley, S.M. and Kale, M.U. (2015). Assessment of precipitation deficit using cropwat. Internat. J. Agric. Engg., 8(1) : 109-115. 